\title{
Association Between Social Capital and Performance Among Core Members of Chinese Ngos in Aids Prevention and Control: A Cross-sectional Study
}

Lingzhi Sang

School of Health Services Management, Anhui Medical University

Meng Liu

School of Health Services Management, Anhui Medical University

Xiaoru Xu

Second Hospital of Anhui Medical University

Zhongliang Bai

School of Health Services Management, Anhui Medical University

Xingxi Zhang

School of Health Services Management, Anhui Medical University

\section{Danni Wang}

School of Public Health, Anhui Medical University

Ren Chen ( $\sim$ chenren2006@hotmail.com )

School of Health Services Management, Anhui Medical University

\section{Research Article}

Keywords: Social capital, Performance evaluation, NGOs, HIV, AIDS

Posted Date: March 15th, 2021

DOI: https://doi.org/10.21203/rs.3.rs-279085/v1

License: (c) (i) This work is licensed under a Creative Commons Attribution 4.0 International License. Read Full License 


\section{Abstract}

Background The role of non-governmental organizations in the field of AIDS prevention and control is increasingly being valued in China and even the world. This research aimed to study the status of social capital and performance of core members of non-governmental organizations (NGOs), as well as the relation between the two, in the field of HIV/AIDS prevention and control in China.

Methods We used a multi-stage stratified cluster random sampling method to conduct a survey among 327 core members of 212 NGOs in the field of HIV prevention and control in eight provinces in China from July to December 2015. The questionnaire included items on demographic characteristics of core members, a social capital scale, and an organizational performance scale. We analyzed the data using chi-squared test and logistic regression.

Results From the perspective of social capital, the core personnel of NGOs with extensive social networks and high levels of social support accounted for a relatively low proportion of the total sample, at $29.1 \%$ (95 people) and 36.7\% (120 people), respectively. The chi-squared test results indicated the statistical significance of differences in factors such as educational background of the core personnel. The logistic regression analysis results indicated that trust in social capital was positively correlated with structural performance $(\mathrm{OR}=2.21,95 \% \mathrm{Cl}$ : $1.24-3.95)$. Social support, cohesion, and sense of belonging were correlated to the level of personal authority in performance evaluation $(\mathrm{OR}=2.78,95 \% \mathrm{Cl}: 1.43-5.39)$. The results also showed no statistically significant correlation between social network in social capital and performance level.

Conclusions Improvement in social capital can promote better organizational performance. For the core members of NGOs, improvement in the level of social capital and performance was conducive to playing an active role in HIV/AIDS prevention and control. Our results can provide insights for decision-making and guiding the activities of NGOs engaged in HIV/AIDS prevention and control services.

\section{Background}

AIDS is a malignant infectious disease caused by HIV, and has an exceedingly high mortality rate when left untreated and seriously threatens the survival and development of those infected. ${ }^{[1]}$ In recent years, with joint international efforts, the AIDS epidemic has been effectively controlled, but overall, the situation of AIDS transmission is still not optimistic, and the task of prevention and treatment remains very difficult. In 2019 , approximately 37.9 million people worldwide were infected with HIV/AIDS. ${ }^{[2]}$ By 2020, China had reported 963,000 surviving infections and 316,000 deaths. Meanwhile, from 2011 to 2017 , the number of AIDS cases in China increased by $179.68 \% .^{[3]}$

Tackling the issues caused by HIV/AIDS remains a challenging work faced by many nations. Non-governmental organizations (NGOs), as a supplement to governmental departments, have been considered as an important social force in promoting public health ${ }^{[4-6]}$ and are playing an increasingly active and important role in responding to HIV/AIDS. ${ }^{[7-9]}$ For instance, the relevance of NGOs in the provision of services such as publicity and education, behavioral intervention and care, and assistance has been noted ${ }^{[10]}$ and acknowledged by the United Nations General Assembly and the Chinese government. ${ }^{[11-12]}$ Therefore, more attention should be given to facilitating the development of NGOs in the field of HIV/AIDS control and prevention.

Social capital can be conceptualized from both social cohesion and social network approaches. ${ }^{[13-14]} \mathrm{A}$ broad definition of social capital is that it describes features of society that enable the pursuit of shared objectives. ${ }^{[15]}$ It as a kind of intangible capital that has been well documented in public health research in recent years, particularly regarding its positive role in the treatment of HIV/AIDS-related problems. Frumence et al. ${ }^{[16]}$ found that an increase in individual social capital can promote the reduction of HIV infection in Tanzania. Phillips et al. ${ }^{[17]}$ reported that people with higher social capital in North America have better compliance with AIDS treatment. Moreover, the trust, cooperation, network support, and common vision contained in social capital are also the basic elements for the survival and development of NGOs, and the social capital of core NGO members plays a key role in the development of NGOs. ${ }^{[18]}$ However, little attention has been paid in research to the association between social capital and performance of core members within NGOs.

The present study focused on the relation between the social capital of core members and the performance of NGOs in China. We hoped to provide a new perspective for NGOs to participate in the prevention and control of HIV/AIDS. Indeed, our findings may provide references with Chinese characteristics for international HIV/AIDS prevention and control and the development of social organizations.

Our research explored social capital theory and practice based on a Chinese context and sought to compare the relation between the social capital and organizational performance of the core members of two NGOs, namely, Grassroots NGOs and government-organized NGOs(GONGOs). Compared with previous studies, ${ }^{[19]}$ our work further filled the gap in the research on grassroots NGOs in the field of HIV/AIDS prevention and treatment. In particular, the grassroots organizations discussed in this study possessed Chinese characteristics, because they originated in China, as well as similarities and differences with NGOs in other countries. Therefore, whether in China or other countries, our research could enrich the research on NGOs.

\section{Methods}

\section{Study design}

This study was funded by the National Natural Science Foundation of China. Our team has published several academic papers on this topic in relevant Chinese and international journals. Details about the study design and sampling are described elsewhere. ${ }^{[20-23]}$ (Figure.1)

(Figure.1 Sampling process in eight provinces of China)

\section{Data collection}


The selection criteria of core members were as follows: the founders, heads, managers, and members who had made outstanding contributions to the organization, who were recommended by the heads of NGOs, and who had been involved in HIV/AIDS prevention and control services for at least one year. With assistance from CDC staff, respondents were interviewed face-to-face by trained investigators from the Anhui Medical University after they expressed a verbal understanding of the purposes and procedures of the study and then signed consent forms. This study ensured the scientific integrity and accuracy of the questionnaire and data through expert discussion, pilot experiment, on-site quality control, questionnaire double entry test, and other methods in the first, middle, and later stages of the study.

\section{Ethics statement}

This study was approved by the Biomedical Ethics Committee of Anhui Medical University (No. 20131236).

\section{Measurements}

\section{Measurement of social capital}

Based on the World Bank's social capital assessment tool, ${ }^{[24]}$ simplified version of the social capital assessment tool, ${ }^{[25]}$ and social support scale of Xiao, ${ }^{[26]}$ we constructed the assessment tool for social capital and adapted it to the Chinese context.

We measured four dimensions of social capital in this study: social network, trust, social support, cohesion, and sense of belonging. We selected 19 commonly used items corresponding to the four dimensions. We asked the respondents to indicate their agreement using a five-point Likert scale ( $1=$ strongly disagree, 2 = disagree, 3 = neutral, 4 = agree, 5 = strongly agree). The core members' score for social capital was firstly summed according to the scores for the corresponding items, and then the scores for each dimension were determined by confirmatory factor analysis, which were recorded as $\mathrm{CmSC}$ network, $\mathrm{CmSC}$ trust, $\mathrm{CmSC}$ support, and $\mathrm{CmSC}$ sense of belonging. According to the variance contribution rate corresponding to each common factor as the weight, we calculated the comprehensive statistics of social capital. The individual and total scores for each dimension were assigned as high level according to a score ${ }^{3} 0$ and low level according to a score $<0$, respectively, to dichotomize the measure into two-category variables. The Cronbach's a of the questionnaire was 0.80 , indicating reliable internal consistency in this sample.

\section{Measurementof performance evaluation}

Through expert consultation and demonstration, as well as related pre-experiments, ${ }^{[27]}$ we formulated a performance evaluation questionnaire that included the personal and organizational performance of core NGO members. We chose cooperation and authority as measures of individual performance, and financial operations and business execution capabilities as measures of organizational performance. Cooperation can bring flexibility to labor and capital markets, whereas authority can reflect the personal charm and performance of the core organizational members. Financial operations reflect the stability and sustainability of an organization, whereas business execution capabilities reflect its efficiency.

We used four questions to measure performance: (1) Do you think you have authority in the organization? (2) Do you take the initiative to seek cooperation with relevant organizations? (3) Do you think the organization has good business execution ability? (4) Do you think the organization has a good financial operation? Response options were measured on a five-point scale designed specifically for this study, ranging from "very poor" (1 point) through "neutral" (3 points) to "very well" (5 points). Performance was dichotomized into two groups by taking the median of each respondents' performance as the cut-off point. The Cronbach's alpha value was 0.92 .

\section{Other variables}

We also collected information on the following variables: age $(£ 30,31-45,>45$ years), sex (male, female), marital status (married/cohabiting, divorced/widowed, single), education (high school and below, college and above), personal background (medical, non-medical). Information on NGOs included the registration status with the Home Affairs Bureau (registered, unregistered) and prevalence of HIV/AIDS in the region served (low, medium, high) was collected as well.

\section{Statistical analysis}

First, we prepared the descriptive statistics on the sample. Specifically, we used numerical values and percentages to describe the demographic characteristics, social capital, and performance of the participants. We employed a chi-squared test to examine the difference between organization types. The two types were grassroots NGOs and GONGOs.

Second, we established a binary logistic regression model and used the forced entry method to estimate the relation between social capital and the performance and demographic characteristics of the participants. Logistic regression and multiple logistic regression were used for single-factor analysis, and the odds ratios (ORs) and 95\% confidence intervals (Cls) were calculated.

Finally, we used EpiData 3.1 for data entry and double-entry error detection, and IBM SPSS Statistics for Windows, Version 20.0 (Armonk, NY: IBM Corp.) for statistical analysis. We set the significance level at $p<0.05$.

\section{Results}

\section{Socio-demographic characteristics of participants}


We collected and finally analyzed 327 valid questionnaires. Among the respondents, $219(67.0 \%)$ were from grassroots NGOs and 108 (33.0\%) were from GONGOs; most of the respondents were men (61.5\%), married/cohabiting (56.8\%), and with a bachelor's degree or above (65.1\%). Only $32.7 \%$ of them had a medical background. Those from registered NGOs accounted for $32.7 \%$, and those from high-prevalence areas accounted for $54.1 \%$. Significant differences between grassroots NGOs and GONGOs (government-organized non-governmental organizations)in terms of marital status, education level,professional background, registration status, HIV/AIDS prevalence, and other variables were observed $(\mathrm{P}<0.05)$. (Table1)

\section{Distribution of Social Capital and Performance of Participants}

Regarding the four dimensions of social capital, 95 core members of NGOs (29.1\%) had extensive social networks, 208 (63.6\%) had a high level of trust, 120 (36.7\%) had a high level of social support, and 191 (58.4\%) had a strong sense of cohesion and belonging. Compared with GONGOs, grassroots NGOs had a lower proportion of core members with extensive social networks but a higher proportion with strong cohesion and sense of belonging.

In the performance indicators, the results showed that $76.8 \%$ of the core members of NGOs believed that they had organizational authority, $69.7 \%$ believed that they could take the initiative to seek cooperation, $57.8 \%$ believed that the organization's business implementation capacity was strong, and $60.6 \%$ believed that the organization's financial operation was in good condition. We found statistical differences between grassroots NGOs and GONGOs in terms of cooperation seeking and business execution ability. (Table 2)

\section{Logistic regression Analysis}

The univariate model revealed that being over 45 years old could increase the level of authority of individuals in the organization. Core members who were older than 45 years, had a medical background, and worked in registered NGOs and GONGOs(Government-Organized Non-Governmental Organizations) were more likely to seek cooperation actively with relevant institutions. The following demographic variables were likewise positively correlated with the good business execution ability and financial operation status of NGOs: older than 45 years old, married/cohabiting status, and from registered organizations. Compared with the reference group(variable group to be referenced), social capital was generally positively correlated with performance.( Table 3)

The multi-factor model showed that an age of over 45 years, a high degree of trust, and a high level of social support were positively correlated with performance levels. Core members over the age of 45 years were more authoritative in the organization $(\mathrm{OR}=4.37 ; 95 \% \mathrm{Cl}$ : $1.64-11.63)$ and more willing to seek cooperation actively $(\mathrm{OR}=5.00 ; 95 \% \mathrm{Cl}$ : $2.10-12.17)$. Their organization also tended to have good business execution skills $(\mathrm{OR}=2.88,95 \% \mathrm{Cl}$ : $1.24-$ 6.67). People with high trust $(\mathrm{OR}=2.00 ; 95 \% \mathrm{Cl}: 1.15-3.47)$, high social support rate $(\mathrm{OR}=1.88,95 \% \mathrm{Cl}: 1.05-3.37)$, high cohesion and sense of belonging $(\mathrm{OR}=1.92,95 \% \mathrm{Cl}: 1.13-3.67)$ were more willing to seek cooperation actively. Similarly, people with high trust $(\mathrm{OR}=2.98,95 \% \mathrm{Cl}: 1.78-4.98)$, high social support rate $(\mathrm{OR}=1.84,95 \% \mathrm{Cl}: 1.09-3.13)$, people with high cohesion and sense of belonging $(\mathrm{OR}=2.33,95 \% \mathrm{Cl}: 1.40-3.88)$ are more likely to have good business execution skills. Regarding performance evaluation, financial operation was only statistically significant in terms of the level of trust in the social capital dimension (OR $=3.42,95 \% \mathrm{Cl}$ : 2.04-5.73). Meanwhile, we did not find a correlation between social networks and performance $(p>0.05)$. ( Table 4$)$

\section{Discussion}

\section{Relationship between the characteristics of core members and organizational performance}

Our results indicated that the core members of NGOs had a low level of social capital, and the overall organizational performance level was not high. Previous research on $\mathrm{China}^{[28]}$ has identified similar trends, indicating that the problems that existed before our investigation had not been effectively resolved.

We found that older core members in grassroots organizations had better job performance compared with younger members. The reason may be that the experience and wisdom accumulated with age could guide them to perform better. Younger core members may need to consult older core members for more experience. Meanwhile, those with higher education and professional medical degrees had a higher performance level, which also indicated the importance of education. A stable marital status also demonstrated a correlation with better organizational performance, indicating that harmony in one's family life has profound effects on working status, in line with traditional Chinese ethics. ${ }^{[29]}$ NGO members from regions with different HIV/AIDS epidemic intensity reported different organizational performance levels, highlighting the impact of one's environment on work status.

\section{Relationship between social capital and performance}

We observed a certain correlation between the social capital and performance of the core members of NGOs: the higher the degree of trust and social support, the stronger the cohesion and sense of belonging of the core members, and the more beneficial to the organization's performance improvement.

We also noted a positive correlation between trust level and performance. Trust is one of the five pillars of ethics in China and has an important impact on Chinese people's psychology and behavior. ${ }^{[29]}$ Winning trust may be the basis for performing well in HIV/AIDS prevention and control. Moreover, a study ${ }^{[30]}$ on the social capital of 188 hospital management committee members in Europe, according to the two dimensions of trust and value recognition, showed that a higher level of social capital correlates with a higher score for the quality of the hospital management system $(A O R=1.41)$. The concordance between their results and ours points to the similarities between Eastern and Western countries in the relation between trust level and performance, which can be used as a new discovery for further exploration.

Meanwhile, most core members reported a low level of social support, especially those in grassroots NGOs. This tendency may be related to the current national conditions in China, where the scale of NGOs in most communities and rural areas remains small. In some underdeveloped areas (such as the western part of China), NGOs lack funding support and human resources and rely on single financing. They often fall into the predicament of impeded operation and development. ${ }^{[1]}$ However, our results pointed to a positive correlation between social support and individual performance, as similarly reported 
in Laos by Sato et al. ${ }^{[32]}$ They found a positive correlation between social support and the self-evaluation performance of primary health workers (AOR: 1.87; $95 \% \mathrm{Cl}: 1.27-2.76)$, thus demonstrating the positive role of social support in improving individual performance. As this problem may be common in Asian developing countries, the development of grassroots NGOs urgently requires and greater attention. Relevant departments may start with financing channels and the deployment of human resources, taking into account material and non-material conditions, and point out the direction for the development of grassroots organizations.

The core members of NGOs usually have a "comfortable feeling," which can promote "democracy" and "sensitivity" within the organization, thereby bringing the organization together and promoting active participation. ${ }^{[3]}$ These feelings explain their choice to work in non-profit organizations. Their inherent sense of cohesion and belonging to the organization make them more serious about their work. Our results showed that a strong sense of cohesion and belonging could increase the authority, cooperativeness, and job execution ability of core members. A survey on social organizations from a university in China ${ }^{\text {[34] }}$ revealed that when members of the organization identify with their team, they will show more supportive behaviors and have a higher sense of organizational identity, and even call for other people to participate in their organization. A Japanese study ${ }^{[35]}$ likewise found a statistical correlation between sense of belonging and individual performance. However, the same study also found no statistical correlation between the cohesion of core members and the financial performance of the organization. The reason for the difference in results may be the difference in management perspectives between professionals in China and Japan. Japanese organizations tend to be hampered by such issues as overly strict management thinking, poor treatment of members, and income instability. Consequently, the job satisfaction of members suffers, which could then hinder the effective operation of the organization.

We also found no statistical correlation between core members' social networks and performance, in contrast with previous research. ${ }^{[36]}$ One possible explanation is that because the boundaries of social organizations in China are not clear, the core individuals of NGOs in the field of HIV/AIDS prevention, despite having outstanding personal abilities, may inevitably rely on "personal connections" to obtain benefits and resources, leading to them maintaining their existing social relations. ${ }^{[37]}$ However, this kind of interpersonal relationship is rife with negative behavioral habits and psychological dependence that could hinder the institutionalization and standardization of social organizations in the field of HIV/AIDS prevention and treatment in China. In other words, the perennial issue of reliance on personal connections poses risks and hidden dangers to the development of NGOs. Government regulatory authorities are thus advised to pay close attention to this issue.

Social and political theorists from Locke and Tocqueville to Putnam have emphasized the importance of social capital. ${ }^{[38]}$ In China, social capital has also gradually attracted much-deserved attention. Therefore, the level of social capital of the core members of NGOs should be systematically improved. Stakeholders should consider leveraging interpersonal trust and social networks in improving the level of social support and sense of belonging of NGO members. Moreover, promoting the improvement of individual and organizational performance should be viewed as inseparable to this thrust.

Core members should also be encouraged to share social capital with non-core employees of the organization, and to cultivate and improve the stock of social capital (e.g., social networks). Non-core employees should establish good relationships with volunteers and even customers, and actively communicate with them, to maximize their personal capabilities as members of the organization. Such a direction would be equally beneficial to the social capital improvement of both individuals and organizations, as well as enable the promotion of the development of the field and cause of HIV/AIDS prevention and treatment.

Our results can also be used to establish evidence-based models to guide organization in improving the prevention and control of HIV/AIDS.

\section{Limitations}

Despite implementing quality control measures before the field survey and data analysis, our study still has some limitations. First, the cross-sectional research design used in our study could not derive the causal relations between the social capital and performance of core NGO members. Second, the eight provinces we studied had different economic and cultural backgrounds, which may affect the level of social capital and, therefore, the results. Finally, data on social capital and performance evaluation were obtained from the same person (self), which may have introduced bias owing to the lack of external evaluation and opinions.

\section{Conclusions}

Our research found a correlation between social capital and NGO performance. China may not be able to make full use of the role and contribution of social capital to improve the capabilities of organizational leaders and the efficiency of NGOs. The various dimensions of social capital shown in the research would help promote the development of NGOs, especially grassroots NGOs. Meanwhile, the characteristics of core personnel should not be ignored-stakeholders ought to examine this issue from the perspective of individuality. As a developmental policy tool, social capital deserves further consideration and practical research.

\section{Abbreviations}

NGOs:Non-governmental organizations; HIV: Human Immunodeficiency Virus;AIDS: acquired immunodeficiency syndrome; GONGOS:government-organized non-governmental organizations; CmSC:Core member Social Capital; AOR:Adjusted odd ratio

\section{Declarations}

Acknowledgments 
The authors want to thank the participants and all those who were involved in the surveys in the study. Also, special thanks to the Centers for Disease Control and Prevention in Yunnan, Sichuan, Hunan, Hubei, Shandong, Anhui, Jilin, and Gansu provinces for assistance throughout the project. We would like to thank Editage (www.editage.cn) for English language editing.

\section{Funding}

This work was supported by the National Natural Science Foundation of China (grant no. 71874002 and no. 71303007) and the Faculty Doctoral Fellowship of Anhui Medical University (Grant No. XJ201702).

\section{Ethics approval and consent to participate}

The study was approved by the Ethical Committee of Anhui Medical University (AMUREC: 20131236) and the study team obtained informed consent from all participants. All methods were in accordance with the 1964 Helsinki declaration and its later amendments or comparable ethical standards. The participants were also well informed that completion of the questionnaire signified their informed consent.

\section{Availability of data and materials}

The datasets used and/or analysed during the current study are available from the corresponding author on reasonable request.Anonymized participant data used in the preparation of this article will be made available on request from the lead author.

\section{Contributors}

$\mathrm{L} S$ and $M \mathrm{~L}$ reviewed the topic related literature, wrote the first draft, analyzed the data and revised the manuscript. $\mathrm{X}$ and $\mathrm{Z} B$ performed the study coordination and data collection. X Z performed study concept, data collection and study supervision. R C and D W performed the study concept and design, obtained funding and carried out study supervision and revision of the manuscript; guarantor for the study. All authors: checked, interpreted results and approved the final version, contributing to the paper equally.

\section{Consent for publication}

Not applicable.

\section{Competing interests}

The authors have declared that no competing interests exist.

\section{References}

1. Murphy RL, Phair JP. AIDS. Compr Ther. 1988 Jan;14(1):3-12. PMID: 3277764.

2. Hamarsheh O. HIV/AIDS in Palestine: A growing concern. Int J Infect Dis. 2020 Jan; 90:18-20.

3. Chinese Center for Disease Control and Prevention, STD / AIDS Prevention and Control Center, STD Control Center. Progress of national AIDS / STD epidemic situation and main prevention and control work in December 2016. AIDS / STD in China.2016;22 (2): 69.

4. Zhang H, Hsieh E, Wang L, Liao S. HIV/AIDS Among Female Sex Workers in China: Epidemiology and Recent Prevention Strategies. Curr HIV/AIDS Rep. 2020;17(2):151-160.

5. Poutiainen C, Berrang-Ford L, Ford J, Heymann J. Civil society organizations and adaptation to the health effects of climate change in Canada. Public Health. 2013; 127:403-409.

6. Marta M, Camila R. Civil society organizations in the prevention of sexually transmitted infections among female sex workers, in Portugal. [http://www.scielo.br/ scielo.php?pid = S0104-12902014000100077\&script = sci_ arttext\&tlng = en] (Accessed 27 March, 2015)

7. Kakietek J, Geberselassie T, Manteuffel B, et al. It takes a village: Communitybased organizations and the availability and utilization of HIV/AIDS-related services in Nigeria. AIDS Care. 2013; 25 Suppl 1:S78-S87.

8. Cai R. Global Funds freeze for China: Time to consider the role of NGOs in the country. [http://www.bmj.com/ rapid-response/2011/11/03/global-fundsfreeze-chinatime-consider-role-ngos-country ](Accessed July 8, 2016)

9. Zhang G, Zhu YK, Wang X, et al. Application of funds for Chinese social organizations to participate in AIDS prevention and control work and government investment in 2014. Miscellaneous Chronicles of Chinese Preventive Medicine.2017;51 (3): 232-236.

10. Li H, Kuo NT, Liu H, Korhonen C, et al. From spectators to implementers: Civil society organizations involved in AIDS programmes in China. Int $\mathrm{J}$ Epidemiol.2010; 39 Suppl 2:ii65-ii71.

11. The State Council The People's Republic of China. China issues five-year plan on AIDS prevention. [http://english.gov.cn/policies/latest_releases/2017/02/05/content_281475559721293.htm]. (Accessed 5 February 2017)

12. The special session of the United Nations General Assembly on AIDS. Declaration of commitment on HIV / AIDS.

13. Moore S, Kawachi I (2017) Twenty years of social capital and health research: a glossary. J Epidemiol Community Health 71(5):513-517.

14. Ehsan A, Klaas HS, Bastianen A, Spini D (2019) Social capital and health: a systematic review of systematic reviews. SSM Popul Health 8:100425.

15. McKenzie K, Whitley R, Weich S (2002) Social capital and men-tal health. Br J Psychiatry 181(4):280-283Kaufman J. HIV, sex work, and civil society in China. J Infect Dis. 2011; 204 Suppl 5:S1218-S1222. 
16. Frumence G, Emmelin M, Eriksson M, et al. Access to social capital and risk of HIV infection in Bukoba urban district, Kagera region, Tanzania. Arch Public Health. 2014;72(1):38.

17. Phillips JC, Webel A, Rose CD, et al. Associations between the legal context of HIV, perceived social capital, and HIV antiretroviral adherence in North America. BMC Public Health. 2013;13:736.

18. Hasmath R, Hsu JYJ. NGOs in China: Issues of good governance and accountability. Asia Pacific Journal of Public Administration. 2008;30(1):1-11.

19. Zhao R, Chen R, Zhang B, Ma Y, Qin X, Hu Z. The Chinese version of monitoring and evaluation system strengthening tool for human immunodeficiency virus (HIV) capacity building: Development and evaluation. Biosci Trends. 2015 Aug;9(4):259-65.

20. Ma Y, Qin X, Chen R, Li N, Chen R, Hu Z. Impact of individual-level social capital on quality of life among AIDS patients in China. PLoS One. 2012;7(11)

21. Wang D, Mei G, Xu X, et al. Chinese non-governmental organizations involved in HIV/AIDS prevention and control: Intra-organizational social capital as a new analytical perspective. Biosci Trends. 2016;10(5):418-423.

22. Xu X, Chen R, Wang D et al. Research on the relationship between social capital and performance of core members of community organizations in the field of AIDS prevention and treatment[J].Chinese Journal of Preventive Medicine,2017,51(11):971-976.

23. Zhang W, Wang D, Qin X et al. Research on the external social capital and organizational performance of civil society organizations in the field of AIDS prevention and treatment[J].Chinese Health Policy Research,2017,10(10):49-53.

24. World Bank. Measuring social capital: an integrated questionnaire [EB/OL].[http://documents.worldbank.org/curated/en/515 261 468 $740392133 /$ pdf/ 281100PAPEROMeasuring0social0capital.pdf.] (Accessed 10 January, 2017)

25. De Silva MJ, Harpham T, Tuan T, et al. Psychometric and cognitive validation of a social capital measurement tool in PeruandVietnam.SocSciMed.2006;62(4):941-953.

26. Xiao SY. Theoretical basis and research application of Social support rating scale. Journal of Clinical Psychiatry.1994; (2): 98-100.

27. McKinnon, Madeleine $\mathrm{C}$ et al. "Impact evaluation to communicate and improve conservation non-governmental organization performance: the case of Conservation International." Philosophical transactions of the Royal Society of London. Series B, Biological sciences vol. 370,1681 (2015): 20140282.

28. Meng T, Chen H. A multilevel analysis of social capital and self-rated health: evidence from China. Health Place. 2014;27:38-44.

29. Mao X. Chinese ethics. Nature. 1996;384(6608):404.

30. Hammer A, Arah OA, DerSarkissian M et al. The Relationship between Social Capital and Quality Management Systems in European Hospitals: A Quantitative Study. PLoS ONE.2013;8(12): e85662.

31. Kaufman J. HIV, sex work, and civil society in China. J Infect Dis. 2011; 204 Suppl 5:S1218-S1222.

32. Sato Y, Pongvongsa T, Nonaka D, et al. Village health volunteers' social capital related to their performance in Lao People's Democratic Republic: a crosssectional study. Bmc Health Services Research. 2014; 14.

33. Moran, Peter. Structural vs. Relational Embeddedness: Social Capital and Managerial Performance. Strategic Management Journal. 2005; 26 (12):112951

34. Tian L, Tu S, Wang Y, et al. Social network analysis of interpersonal communication characteristics of college students. Advances in Psychology.2015; 05 (01).

35. Inoue A, Tsutsumi A, Eguchi H, et al. Workplace social capital and refraining from seeking medical care in Japanese employees: a 1-year prospective cohort study. BMJ Open. 2020;10(8).

36. Ma Y. Study on the relationship and Strategy between Social Capital and AIDS Prevention and Control. Anhui Medical University.2013.

37. Zhang J. Rethinking of Karisma, publicity and the "differential order pattern" of Chinese society. Society. $2010 ; 30$ (5): 1-24.

38. Newton K. Trust, Social Capital, Civil Society, and Democracy. International Political Science Review.2001; 22(22):201-14.

\section{Tables}

Table 1 Descriptive results of core members in NGOs characteristics [N=327,n (\%)] 


\begin{tabular}{|c|c|c|c|c|c|}
\hline Variables & $\begin{array}{l}\text { Overall } \\
(n=327)\end{array}$ & $\begin{array}{l}\text { Grassroots NGOs } \\
(n=219)\end{array}$ & $\begin{array}{l}\text { GONGOs } \\
(n=108)\end{array}$ & $c^{2}$ value & $p$ value \\
\hline Age(years) & & & & 5.55 & 0.06 \\
\hline$£ 30$ & $83 \llbracket 25.4 \rrbracket$ & $61 \llbracket 27.9 \rrbracket$ & $22 \varangle 20.4 \rrbracket$ & & \\
\hline $31-45$ & $152 \rrbracket 46.5 \rrbracket$ & $105 \rrbracket 47.9 \rrbracket$ & $47 \rrbracket 43.5 \rrbracket$ & & \\
\hline$>45$ & $92 \llbracket 28.1 \rrbracket$ & $53 \rrbracket 24.2 \rrbracket$ & $39 \llbracket 36.1 \rrbracket$ & & \\
\hline Gender & & & & 0.02 & 0.88 \\
\hline male & 201(61.5) & $134(61.2)$ & $67(62.0)$ & & \\
\hline female & $126(38.5)$ & $85(38.8)$ & $41(38.0)$ & & \\
\hline Marital status & & & & 7.84 & $0.02 *$ \\
\hline Single & 106(32.4) & 81ه37.0凶 & $25 \llbracket 20.4 \rrbracket$ & & \\
\hline Married/cohabitation & $186(56.9)$ & $113(51.6)$ & $73(67.6)$ & & \\
\hline Divorced/widowed & $35(10.7)$ & $25(11.4)$ & $10(9.3)$ & & \\
\hline \multicolumn{6}{|l|}{ Education level } \\
\hline High school or less & 114(34.9) & $89(40.6)$ & $25(23.1)$ & 9.75 & $0.002^{*}$ \\
\hline College or above & $213(65.1)$ & $130(59.4)$ & $83(76.9)$ & & \\
\hline \multicolumn{6}{|l|}{ Major } \\
\hline Non-medical & $220(67.3)$ & $164(74.9)$ & $56(51.9)$ & 17.43 & $<0.001 * *$ \\
\hline Medical & 107(32.7) & $55(25.1)$ & $52(48.1)$ & & \\
\hline \multicolumn{6}{|l|}{ Register } \\
\hline No & $220(67.3)$ & $197(90.0)$ & $23(21.3)$ & 154.88 & $<0.001 * *$ \\
\hline Yes & 107(32.7) & $22(10.0)$ & $85(78.8)$ & & \\
\hline \multicolumn{6}{|c|}{ HIV/AIDS epidemic level } \\
\hline Low & $34(10.4)$ & $20(9.1)$ & $14(13.0)$ & 10.10 & $0.006^{*}$ \\
\hline Middle & $116(35.5)$ & $67(30.6)$ & $49(45.4)$ & & \\
\hline High & $177(54.1)$ & $132(60.3)$ & 45 (41.7) & & \\
\hline
\end{tabular}

GONGOs:Government non-governmental organization

Bold values are statistically significant ${ }^{*} p<0.05 ; * \star p<0.001$

Table 2 The Distribution of Social Capital and Performance of Core Members of NGOs [N=327,n (\%)] 


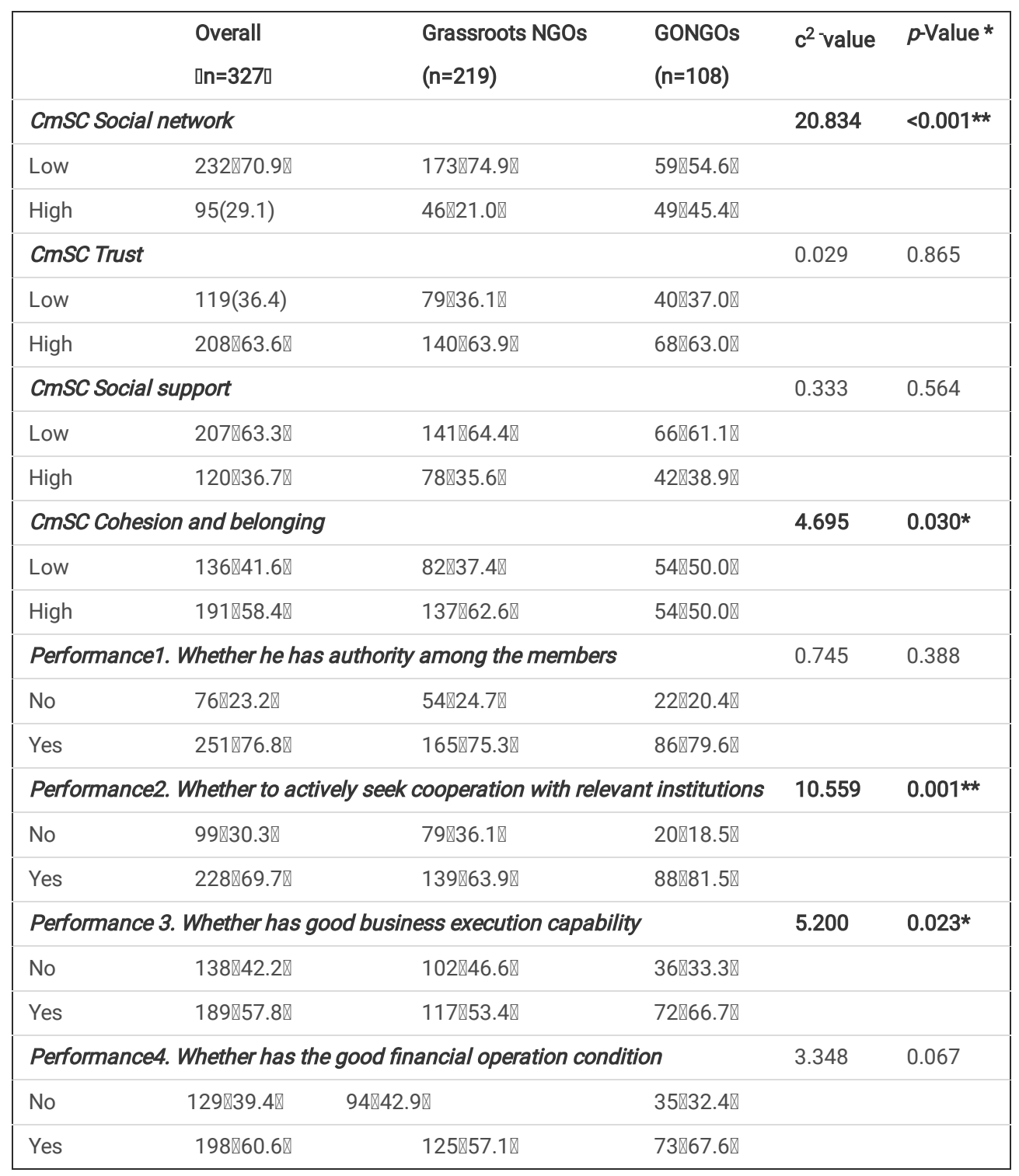

Bold values are statistically significant $₫ * 0<0.05 ; * \star p<0.01$

Table 3 Univariate logistic regression Analysis of the relationship among demographic variables, Social Capital and performance 


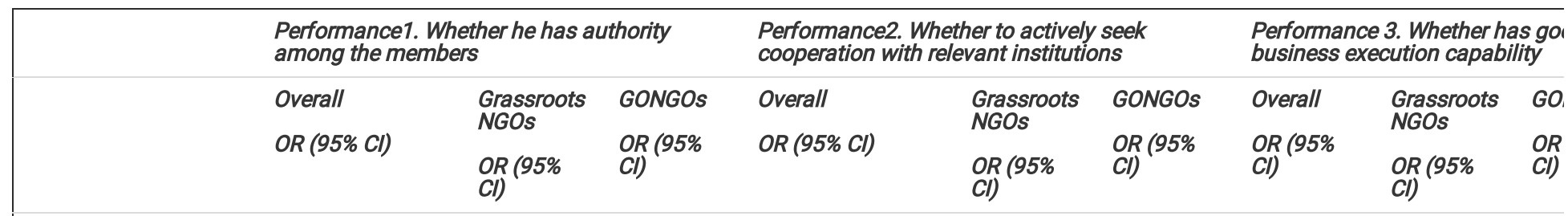

\section{Age(years)}

$£ 30$

$£ 30 \quad$ (reference)

(reference) (reference) (reference)

1.73(0.96 3.11)

$\begin{array}{ll}2.31(1.56- & 0.77(0.24- \\ 4.62)^{*} & 2.51)\end{array}$

$3.12(1.77 \sim 5.47)^{\star \star}$

(reference) (reference)

(reference)

(reference) (ref

$31-45$ $\begin{array}{lll}3.96(1.82 \sim 8.58)^{*} & \begin{array}{ll}4.26(1.65- & 2.57(0.61- \\ 10.99)^{*} & 10.83)\end{array}\end{array}$

$4.74(2.40 \sim 9.36)$ **

$\begin{array}{ll}4.04(2.07- & 1.39(0.43- \\ 7.88)^{* \pi} & 4.47)\end{array}$

$\begin{array}{ll}1.79(1.04- & 1.41(0.75- \\ 3.07)^{*} & 2.67)\end{array}$

3.1
9.0

$>45$

4.74(2.11- $\quad 3.28(0.81-$ $3.07)^{\star}$

$\left.10.70)^{\star *} \quad 13.26\right)$

$\begin{array}{lll}3.89(2.05- & 4.43(1.98- & 3.0 \\ 7.35)^{* *} & 9.93)^{* *} & 9.1\end{array}$

Gender

male

(reference)

(reference) (reference) (reference)

(reference) (reference)

(reference)

(reference) (ref

female

0.77(0.46 1.29)

$0.81(0.43-$

$0.68(0.26-\quad 1.01(0.62 \sim 1.64)$

1.15(0.65-

$0.70(0.26-$

$0.82(0.52-$

$0.83(0.48$

0.71

Marital status

Single

(reference)

(reference)

(1.87)

$1.28)$

1.43)

1.79$$
\text { Divorced/widowed }
$$

\section{Education level}

\begin{tabular}{|c|c|c|c|c|c|c|c|c|c|}
\hline High school or less & (reference) & (reference) & (reference) & (reference) & (reference) & (reference) & (reference) & (reference) & (ref \\
\hline College or above & $1.30(0.76 \sim 2.20)$ & $\begin{array}{l}1.01(0.54- \\
1.88)\end{array}$ & $\begin{array}{l}2.32(0.84- \\
6.42)\end{array}$ & $1.03(0.63 \sim 1.69)$ & $\begin{array}{l}0.77(0.44- \\
1.36)\end{array}$ & $\begin{array}{l}1.56(0.53- \\
4.60)\end{array}$ & $\begin{array}{l}1.05(0.66- \\
1.66)\end{array}$ & $\begin{array}{l}0.90(0.52- \\
1.54)\end{array}$ & $\begin{array}{l}1.1 \\
2.9\end{array}$ \\
\hline
\end{tabular}

\section{Major}

Non-medical

(reference)

(reference) (reference) (reference)

(reference) (reference)

(reference)

(reference) (ref

Medical

1.49(0.84 2.63)

$1.23(0.60$

2.56)

$1.83(0.70-$
$4.82)$

$1.93(1.13 \sim 3.30)$ *

$1.94(0.71-\quad 1.27(0.79$

2.95)

5.33)

2.04)

$0.96(0.52-\quad 1.4$

Register

No

(reference)

(reference) (reference) (reference)

(reference)

(reference)

(reference)

(reference) (ref

$\begin{array}{lll}0.86(0.32- & 1.11(0.36-\quad 2.08(1.21 ~ 3.59) *\end{array}$

1.23(0.48-

$1.30(0.42-$

$\begin{array}{lll}\mathbf{1 . 9 3}(1.19- & 1.29(0.53- & 2.21 \\ \mathbf{3 . 1 3}) * & 3.16) & 5.6 .\end{array}$

\section{HIV/AIDS epidemic level}

\begin{tabular}{|c|c|c|c|c|c|c|c|c|c|}
\hline Low & (reference) & (reference) & (reference) & (reference) & (reference) & (reference) & (reference) & (reference) & (ref \\
\hline Middle & $0.74(0.26 \sim 2.12)$ & $\begin{array}{l}1.15(0.33- \\
4.04)\end{array}$ & $\begin{array}{l}0.30(0.04- \\
2.57)\end{array}$ & $1.26(0.56 \sim 2.83)$ & $\begin{array}{l}1.29(0.47- \\
3.54)\end{array}$ & $\begin{array}{l}1.21(0.28- \\
5.26)\end{array}$ & $\begin{array}{l}1.90(0.88- \\
4.12)\end{array}$ & $\begin{array}{l}1.79(0.65- \\
4.91)\end{array}$ & $\begin{array}{l}2.01 \\
6.81\end{array}$ \\
\hline High & $0.45(0.17 \sim 1.23)$ & $\begin{array}{l}0.62(0.19- \\
1.97)\end{array}$ & $\begin{array}{l}0.24(0.03- \\
2.03)\end{array}$ & $1.31(0.61 \sim 2.84)$ & $\begin{array}{l}1.64(0.63- \\
4.24)\end{array}$ & $\begin{array}{l}1.26(0.29- \\
5.59)\end{array}$ & $\begin{array}{l}1.19(0.57- \\
2.47)\end{array}$ & $\begin{array}{l}0.94(0.37- \\
2.41)\end{array}$ & $\begin{array}{l}2.4 ! \\
8.4 !\end{array}$ \\
\hline
\end{tabular}

\section{Organization type}

Grassroots NGOs

GONGOS

(reference)

$1.28(0.73 \sim 2.24)$

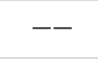

$--$

$--$

(reference)
$\mathbf{2 . 4 8}(1.42 \sim 4.34) *$

(reference)

1.74(1.08$2.82) *$

\section{CmSC Social network}

\begin{tabular}{|c|c|c|c|c|c|c|c|c|c|}
\hline Low & (reference) & (reference) & (reference) & (reference) & (reference) & (reference) & (reference) & (reference) & (ref \\
\hline High & 2.11(1.12 3.99)* & $\begin{array}{l}3.24(1.21- \\
8.68)^{\star}\end{array}$ & $\begin{array}{l}1.26(0.49- \\
3.25)\end{array}$ & $2.51(1.39 \sim 4.52) *$ & $\begin{array}{l}2.79(1.27- \\
6.15)^{\star}\end{array}$ & $\begin{array}{l}1.31(0.49- \\
3.51)\end{array}$ & $\begin{array}{l}2.02(1.22- \\
3.35)^{\star}\end{array}$ & $\begin{array}{l}1.85(0.94- \\
3.64)\end{array}$ & $\begin{array}{l}1.7 \\
4.0\end{array}$ \\
\hline \multicolumn{10}{|c|}{ CmSC Trust } \\
\hline Low & (reference) & (reference) & (reference) & (reference) & (reference) & (reference) & (reference) & (reference) & (ref \\
\hline High & $2.25(1.34 \sim 3.80) *$ & $\begin{array}{l}1.60(0.86- \\
3.00)\end{array}$ & $\begin{array}{l}5.23(1.90- \\
14.37)^{\star}\end{array}$ & $1.84(1.14 \sim .99) *$ & $\begin{array}{l}2.24(1.26- \\
3.97)^{\star}\end{array}$ & $\begin{array}{l}1.17(0.43- \\
3.15)\end{array}$ & $\begin{array}{l}2.94(1.85- \\
4.69)^{\star \star *}\end{array}$ & $\begin{array}{l}2.47(1.40- \\
4.34)^{\star}\end{array}$ & $\begin{array}{l}4.7 \\
11 .\end{array}$ \\
\hline
\end{tabular}




\begin{tabular}{|c|c|c|c|c|c|c|c|c|c|}
\hline Low & (reference) & (reference) & (reference) & (reference) & (reference) & (reference) & (reference) & (reference) & (ref \\
\hline High & $2.93(1.58 \sim 5.43) *$ & $\begin{array}{l}3.60(1.65- \\
7.84)^{\star}\end{array}$ & $\begin{array}{l}1.92(0.68- \\
5.39)\end{array}$ & 1.84(1.10 3.08)* & $\begin{array}{l}1.58(0.87- \\
2.85)\end{array}$ & $\begin{array}{l}3.04(0.94- \\
9.84)\end{array}$ & $\begin{array}{l}1.91(1.19- \\
3.04)^{\star}\end{array}$ & $\begin{array}{l}2.15(1.21- \\
3.80)^{\star}\end{array}$ & $\begin{array}{l}1.4 \\
3.3\end{array}$ \\
\hline \multicolumn{10}{|c|}{ CmSC Cohesion and belonging } \\
\hline Low & (reference) & (reference) & (reference) & (reference) & (reference) & (reference) & (reference) & (reference) & (ref \\
\hline High & $1.79(1.07 \sim 3.01) *$ & $\begin{array}{l}1.81(0.97- \\
3.37)\end{array}$ & $\begin{array}{l}2.01(0.77- \\
5.29)\end{array}$ & $1.69(1.05 \sim 2.71) *$ & $\begin{array}{l}1.57(0.89- \\
2.77)\end{array}$ & $\begin{array}{l}3.77(1.26- \\
11.28)^{*}\end{array}$ & $\begin{array}{l}1.92(1.23- \\
3.00)^{\star}\end{array}$ & $\begin{array}{l}2.77(1.58- \\
4.88) \star \star\end{array}$ & $\begin{array}{l}1.1 \\
2.6\end{array}$ \\
\hline
\end{tabular}

Table 4 Multivariate logistic regression Analysis of the relationship among demographic variables, Social Capital and performance 


\begin{tabular}{|c|c|c|c|c|c|c|c|c|c|}
\hline \multicolumn{3}{|c|}{$\begin{array}{l}\text { Performance1. Whether he has } \\
\text { authority among the members }\end{array}$} & \multicolumn{3}{|c|}{$\begin{array}{l}\text { Performance2. Whether to actively seek } \\
\text { cooperation with relevant institutions }\end{array}$} & \multicolumn{3}{|c|}{$\begin{array}{l}\text { Performance 3. Whether has good } \\
\text { business execution capability }\end{array}$} & \\
\hline Overall & Grassroots & GONGOS & Overall & Grassroots & GONGOS & Overall & Grassroots & GONGOS & 0 \\
\hline$\left.{ }_{C l}\right)(95 \%$ & OR $(95 \%$ & $\begin{array}{l}O R(95 \% \\
C l)\end{array}$ & $\begin{array}{l}\text { OR }(95 \% \\
C l)\end{array}$ & 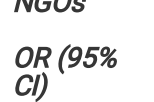 & $\begin{array}{l}O R(95 \% \\
C l)\end{array}$ & $\left.{ }_{C l}\right)(95 \%$ & $\begin{array}{l}\text { OR }(95 \% \\
C l)\end{array}$ & $\begin{array}{l}\text { OR }(95 \% \\
C l)\end{array}$ & $\begin{array}{l}0 \\
C\end{array}$ \\
\hline
\end{tabular}

\section{Age(years)}

$£ 30$

31-45

(reference) (reference) (reference)

(reference)

(reference) (reference)

(reference)

(reference) (reference) (r

(

$>45$

\begin{tabular}{lll}
$2.18(1.02-$ & $2.58(1.07-$ & $3.26(0.44-$ \\
$\mathbf{4 . 6 6})^{*}$ & $\mathbf{6 . 1 9})^{*}$ & $24.09)$ \\
\hline $\mathbf{4 . 3 7}(1.64-$ & $\mathbf{3 . 5 1}(1.15-$ & $14.08(1.07-$ \\
$11.63)^{*}$ & $\mathbf{1 0 . 6 9 ) *}$ & $185.91)$
\end{tabular}

$4.10(1.97-$
$8.52)^{* k}$

$\begin{array}{lll}4.47(1.97- & 31.78(2.32- & 1.59(0.80-\end{array}$

$1.18(0.53-$

2.62)

$\begin{array}{ll}5.41(0.98- & 1 . \\ 29.76) & 2 .\end{array}$

$5.00(2.06$

3.96(1.49- 71.42(4.00-

2.88(1.24

3.98(1.46-

3.04(0.43- 1 .

\section{Gender}

male

(reference)

(reference) (reference)

(reference)

$\left.0.52)^{*} \quad 1.27\right)$

$6.67)^{\star}$

$10.86)^{*}$

21.41)

female

$0.61(0.32-\quad 0.62(0.27-\quad 0.48(0.12-$

$0.86(0.47-$

$1.59)$

(reference) (reference)

(reference)

(reference) (reference) ( $r$

\section{Marital status}

\begin{tabular}{|c|c|c|c|c|c|c|c|c|c|c|}
\hline Single & (reference) & (reference) & (reference) & (reference) & (reference) & (reference) & (reference) & (reference) & (reference) & $(r$ \\
\hline Married/cohabitation & $\begin{array}{l}1.08(0.50- \\
2.33)\end{array}$ & $\begin{array}{l}1.59(0.65- \\
3.93)\end{array}$ & $\begin{array}{l}0.24(0.23- \\
2.11)\end{array}$ & $\begin{array}{l}0.56(0.26- \\
1.18)\end{array}$ & $\begin{array}{l}0.84(0.37- \\
1.93)\end{array}$ & $\begin{array}{l}0.04(0.00- \\
0.63)\end{array}$ & $\begin{array}{l}1.58(0.80- \\
3.11)\end{array}$ & $\begin{array}{l}1.71(0.75- \\
3.90)\end{array}$ & $\begin{array}{l}0.78(0.16- \\
3.79)\end{array}$ & $\begin{array}{l}3 . \\
6 .\end{array}$ \\
\hline Divorced/widowed & $\begin{array}{l}1.27(0.43- \\
3.79)\end{array}$ & $\begin{array}{l}1.20(0.34- \\
4.25)\end{array}$ & $\begin{array}{l}0.91(0.06- \\
13.53)\end{array}$ & $\begin{array}{l}0.49(0.18- \\
1.35)\end{array}$ & $\begin{array}{l}0.55(0.18- \\
1.68)\end{array}$ & $\begin{array}{l}0.09(0.00- \\
1.78)\end{array}$ & $\begin{array}{l}1.92(0.73- \\
5.04)\end{array}$ & $\begin{array}{l}1.87(0.61- \\
5.74)\end{array}$ & $\begin{array}{l}2.51(0.24- \\
26.21)\end{array}$ & $\begin{array}{l}2 . \\
6 .\end{array}$ \\
\hline
\end{tabular}

Education level

High school or less

College or above

(reference) (reference)

(reference)

(reference)

$0.82(0.38$ -

$0.49(0.12-$

$0.70(0.39-$

0.78(0.37-

$0.57(0.19-\quad 0$.

1.75)

1.99)

1.23)

1.63)

1.72)

\section{Major}

Non-medical

1.34(0.68- $\quad 1.09(0.49-\quad 3.76(0.77$

2.66)

2.44)

18.30)

$0.93(0.49$

1.77)

(reference)
$0.74(0.36-$
$1.56)$

(reference)

(reference)

(reference)

(reference) ( $r$

5.28(0.98- 1.04(0.57

$0.83(0.40$

1.71)

$1.73(0.46-1$

28.51) 1.90)

(reference)

(reference)

(reference)

(reference)

(reference)

(reference) (r

1.65(0.882-

1.64(0.69-

1.21(0.31-

$0.83(0.44$

$1.57)$

$0.73(0.32$

1.69)

$\begin{array}{ll}1.29(0.42- & 0 . \\ 3.95) & 1 .\end{array}$

Register

No

(reference)

(reference)

(reference)

(reference

(reference)

(reference)

(2)

(2)

Yes

\begin{tabular}{lll}
$0.80(0.35-$ & $0.91(0.29-$ & $0.75(0.16-$ \\
$1.85)$ & $2.80)$ & $3.58)$ \\
\hline
\end{tabular}

$0.87(0.39$ -

$1.94)$

$\begin{array}{ll}1.19(0.40- & 0.38(0.07- \\ 3.50) & 2.12)\end{array}$

$1.19(0.56-$

2.52)

(reference) (reference) (r

$\begin{array}{lll}1.25(0.43- & 0.77(0.21- & 2 . \\ 3.63) & 2.87) & 4 .\end{array}$

\section{HIVIAIDS epidemic level}

\begin{tabular}{|c|c|c|c|c|c|c|c|c|c|c|}
\hline Low & (reference) & (reference) & (reference) & (reference) & (reference) & (reference) & (reference) & (reference) & (reference) & $(r$ \\
\hline Middle & $\begin{array}{l}0.56(0.17- \\
1.82)\end{array}$ & $\begin{array}{l}1.46(0.35- \\
6.14)\end{array}$ & $\begin{array}{l}0.12(0.01- \\
1.74)\end{array}$ & $\begin{array}{l}1.05(0.40- \\
2.72)\end{array}$ & $\begin{array}{l}1.40(0.42- \\
4.67)\end{array}$ & $\begin{array}{l}2.50(0.28- \\
22.09)\end{array}$ & $\begin{array}{l}1.41(0.57- \\
3.52)\end{array}$ & $\begin{array}{l}1.66(0.51- \\
5.40)\end{array}$ & $\begin{array}{l}1.87(0.36- \\
9.79)\end{array}$ & $\begin{array}{l}1 . \\
3 .\end{array}$ \\
\hline High & $\begin{array}{l}0.43(0.14- \\
1.33)\end{array}$ & $\begin{array}{l}0.80(0.21- \\
2.97)\end{array}$ & $\begin{array}{l}0.12(0.01- \\
1.65)\end{array}$ & $\begin{array}{l}1.46(0.58- \\
3.68)\end{array}$ & $\begin{array}{l}1.74(0.56- \\
5.36)\end{array}$ & $\begin{array}{l}2.03(0.24- \\
17.01)\end{array}$ & $\begin{array}{l}1.67(0.69- \\
4.05)\end{array}$ & $\begin{array}{l}0.92(0.31- \\
2.73)\end{array}$ & $\begin{array}{l}2.44(0.47- \\
12.63)\end{array}$ & $\begin{array}{l}1 . \\
4 .\end{array}$ \\
\hline \multicolumn{11}{|l|}{ Organization type } \\
\hline Grassroots NGOs & (reference) & -- & -- & (reference) & -- & -- & (reference) & -- & -- & $(r$ \\
\hline GONGOs & $\begin{array}{l}1.11(0.47- \\
2.62)\end{array}$ & -- & -- & $\begin{array}{l}2.79(1.22- \\
6.39)^{\star}\end{array}$ & -- & -- & $\begin{array}{l}1.54(0.72- \\
3.31)\end{array}$ & -- & -- & $\begin{array}{l}0 . \\
1 .\end{array}$ \\
\hline \multicolumn{11}{|c|}{ CmSC Social network } \\
\hline Low & (reference) & (reference) & (reference) & (reference) & (reference) & (reference) & (reference) & (reference) & (reference) & $(r$ \\
\hline High & $\begin{array}{l}1.25(0.59- \\
2.63)\end{array}$ & $\begin{array}{l}1.95(0.67- \\
5.70)\end{array}$ & $\begin{array}{l}0.78(0.19- \\
3.24)\end{array}$ & $\begin{array}{l}1.43(0.72- \\
2.85)\end{array}$ & $\begin{array}{l}2.14(0.88- \\
5.20)\end{array}$ & $\begin{array}{l}0.80(0.20- \\
3.21)\end{array}$ & $\begin{array}{l}1.21(0.66- \\
2.24)\end{array}$ & $\begin{array}{l}1.25(0.57- \\
2.76)\end{array}$ & $\begin{array}{l}1.28(0.40- \\
4.05)\end{array}$ & 1. \\
\hline \multicolumn{11}{|l|}{ CmSC Trust } \\
\hline Low & (reference) & (reference) & (reference) & (reference) & (reference) & (reference) & (reference) & (reference) & (reference) & $(r$ \\
\hline High & $\begin{array}{l}2.21(1.24- \\
3.95)^{\star}\end{array}$ & $\begin{array}{l}1.45(0.71- \\
2.96)\end{array}$ & $\begin{array}{l}10.22(2.62- \\
39.78)^{*}\end{array}$ & $\begin{array}{l}2.00(1.15- \\
3.47)^{\star}\end{array}$ & $\begin{array}{l}2.54(1.32- \\
4.91)^{\star}\end{array}$ & $\begin{array}{l}1.27(0.35- \\
4.60)\end{array}$ & $\begin{array}{l}2.98(1.78- \\
4.98)^{\star \star}\end{array}$ & $\begin{array}{l}2.39(1.26- \\
4.53)^{\star}\end{array}$ & $\begin{array}{l}6.49(2.35- \\
17.94)^{\star \star}\end{array}$ & $\begin{array}{l}3 \\
5\end{array}$ \\
\hline
\end{tabular}




\begin{tabular}{|c|c|c|c|c|c|c|c|c|c|c|}
\hline Low & (reference) & (reference) & (reference) & (reference) & (reference) & (reference) & (reference) & (reference) & (reference) & $(n$ \\
\hline High & $\begin{array}{l}2.78(1.43- \\
5.39)^{\star}\end{array}$ & $\begin{array}{l}3.24(1.38- \\
7.57)^{\star}\end{array}$ & $\begin{array}{l}3.88(0.97- \\
15.49)\end{array}$ & $\begin{array}{l}1.88(1.05- \\
3.37)^{\star}\end{array}$ & $\begin{array}{l}1.60(0.80- \\
3.22)\end{array}$ & $\begin{array}{l}5.64(1.32- \\
24.04)\end{array}$ & $\begin{array}{l}1.84(1.09- \\
3.13)^{\star}\end{array}$ & $\begin{array}{l}1.90(0.98- \\
3.70)\end{array}$ & $\begin{array}{l}1.90(0.68- \\
5.33)\end{array}$ & $\begin{array}{l}1 . \\
2 .\end{array}$ \\
\hline \multicolumn{11}{|c|}{ CmSC Cohesion and belonging } \\
\hline Low & (reference) & (reference) & (reference) & (reference) & (reference) & (reference) & (reference) & (reference) & (reference) & $(r$ \\
\hline High & $\begin{array}{l}1.86(1.06- \\
3.27)^{\star}\end{array}$ & $\begin{array}{l}1.56(0.79- \\
3.11)\end{array}$ & $\begin{array}{l}2.00(0.55- \\
7.30)\end{array}$ & $\begin{array}{l}1.92(1.13- \\
3.67)^{\star}\end{array}$ & $\begin{array}{l}1.37(0.72- \\
2.58)\end{array}$ & $\begin{array}{l}7.22(1.59- \\
32.81) *\end{array}$ & $\begin{array}{l}2.33(1.40- \\
3.88)^{\star}\end{array}$ & $\begin{array}{l}3.15(1.64- \\
6.03)^{\star}\end{array}$ & $\begin{array}{l}1.58(0.57- \\
4.37)\end{array}$ & 1. \\
\hline
\end{tabular}

\section{Figures}

Eight provinces were randomly selected in proportion to the high, medium, and low AIDS endemic areas of the country

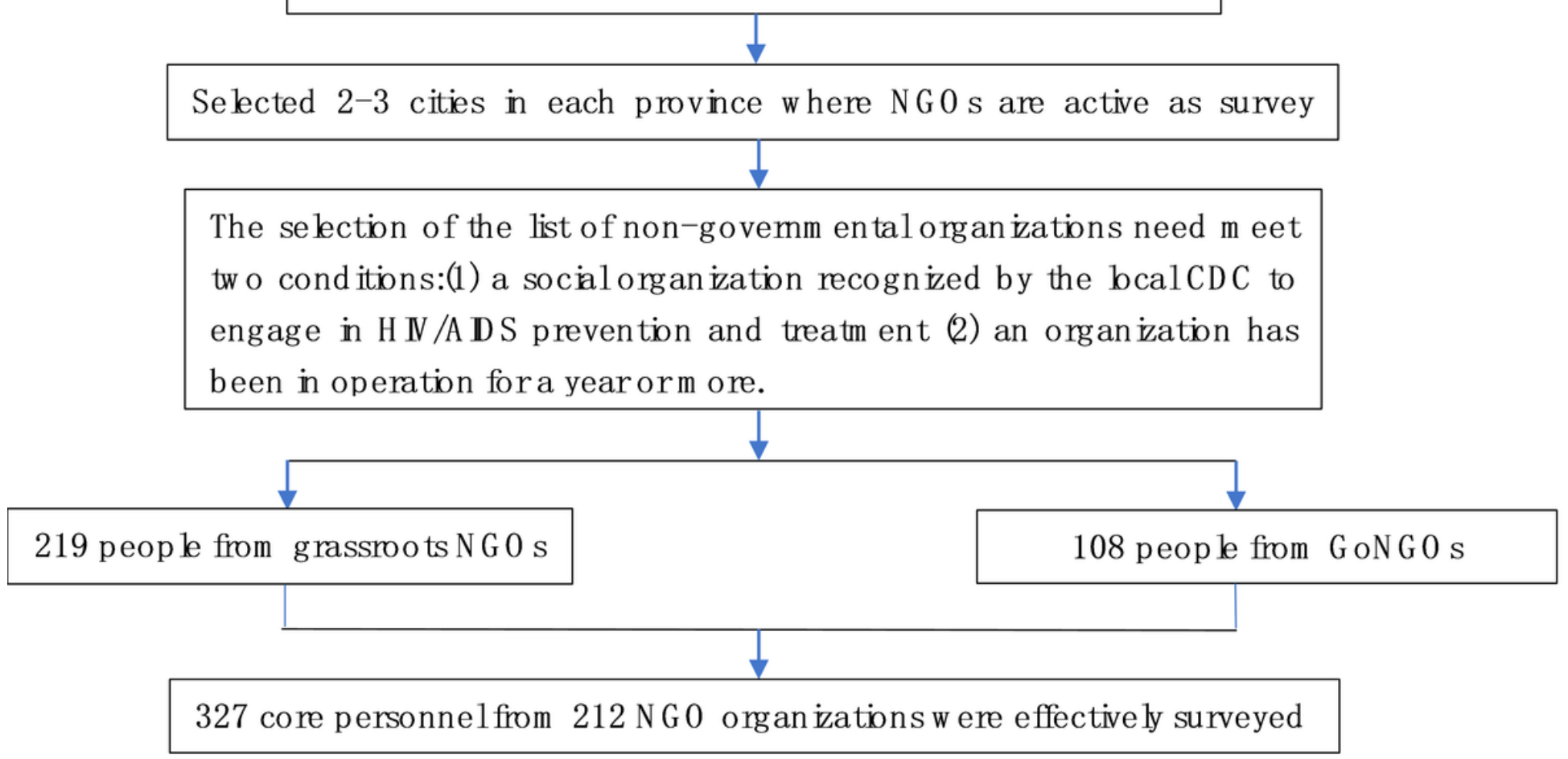

Figure 1

Sampling process in eight provinces of China 